\title{
Technical Note: A rotary seed processor for removing pubescence from seed of prairie grasses
}

\author{
K.P. VOGEL, R. A. MASTERS, P.J. CALLAHAN, AND K. GRAMS
}

Authors are research geneticist, rangeland scientist, and research technicians, respectively, USDA-ARS, 344 Keim Hall, Univ. of Nebraska, P.O. Box 830937, Lincoln, Nebr. 68583-0937.

\begin{abstract}
Many of the perennial prairie grasses that are used in restoration plantings in the central Great Plains have seed appendages such as awns and pubescence that make seed flow through planters difficult. We have developed a rotary seed processor that efficiently processes small breeder or experimental lots of seed that can then be easily planted with small plot cone planters or conventional planters. The processor consists of a metal cylinder that is lined with corrugated rubber and a rotating center shaft with rubber paddles. Processing can be controlled by varying shaft rotation speed and processing time. A top-opening, full length trap door allows for easy loading and the cylinder can be inverted to dump out processed seed. The processor has been used successfully for several years on big bluestem [Andropogon gerardii Vitman], indiangrass [Sorghastrum nutans (L.) Nash], little bluestem [Schizachyrium scoparium (Michaux) Nash], prairie sandreed [Calamovilfa longifolia (Hook.) Scribner], and blue grama [Bouteloua gracilis (Willd. ex Kunth) Lagascaex Griffiths] seed. By removing seed appendages and pubescence, seed bulk is reduced and seed density and flow ability are improved. The processing operation is relatively gentle and seed germination per unit weight of seed is improved.
\end{abstract}

Key Words: seed processing, seed conditioning, germination.

The purpose of this report is to describe a rotary seed processor that can be used to process small seed lots of chaffy native grasses for use in breeding and revegetation research. Many of the perennial prairie grasses used in the Great Plains such as big blucstem [Andropogon gerardii Vitman], indiangrass [Sorghastrum nutans (L.) Nash], little bluestem [Schizachyrium scoparium (Michaux) Nash], prairie sandreed [Calamovilfa longifolia (Hook.) Scribner], and blue grama [Bouteloua gracilis (Willd. ex Kunth) Lagascaex Griffiths] have seed appendages including awns and pubescence. In research trials, grasses need to be seeded accurately and uniformly across plots at controlled rates. Most small research planters are not designed to plant the chaffy seed of these grasses (Vogel 1978). Seed processing equipment such as hammer mills and debearders have been modi-

Research is from USDA-ARS and University of Nebraska cooperative forage and range research programs affiliated with the Agronomy Department and the Center for Grassland Studies, University of Nebraska. Journal series no. 12081, Nebraska Agricultural Experiment Station.

Manuscript accepted 8 Mar. 1998.

\section{Resumen}

Semillas de muchos pastos perennes que son usados en la restauración de praderas en las Grandes Planicies centrales, poseen accesorios como aristas y/o pubescencias que dificultan el paso de las semillas a través de sembradoras convencionales. Para efectuar siembras con éstas semillas, las sembradoras tendrian que estar específicamente diseñadas para plantar material relativamente voluminoso y sin peso, al menos que las semillas sean procesadas para remover tales cuerpos accesorios. Nosotros hemos desarrollado un procesador de semilla que procesa eficientemente pequeños lotes de semillas con fines de reproducción de germoplasma o experimentales. De ésta manera, las semillas podrán ser fácilmente sembrados con un sembrador de cono para pequeñas parcelas, o con sembradoras convencionales. El procesador consiste de un cilindro o tambor de metal forrado en su interior con hule corrugado. Paletas de hule adjuntas a un eje que atraviesa el cilindro y que son rotadas por polea, golpean las semillas. El proceso puede ser controlado variando el tamaño de polea y la velocidad de rotación, y por el tiempo que la semilla permanece rotando dentro de la unidad. El cilindro cuenta con una puerta en la parte superior que permite el fácil acceso de la semilla dentro de la unidad. Cuando la semilla ha sido procesada, el cilindro puede ser invertido para retirar la semilla de la unidad. El procesador ha sido exitosamente usado por varios años en big bluestem (Andropogon gerardii Vitman), indiangrass [Sorghastrum nutans (L.) Nash], little bluestem [Schizachyrium scoparium (Michx.) Nash], prairie sandreed [Calamovilfa longifolia (Hook.) Scribn.], and blue grama [Bouteloua gracilis (Willd. ex Kunth) Lagasca ex Griffiths] seed. La remoción de las aristas y pubescencias disminuyen el volumen de la semilla, y la densidad y flujo dentro de la sembradora son entonces mejorados. El proceso de operación es relativamente suave para las semillas y la germinación por unidad de peso es mejorada.

fied for processing chaffy prairie grasses but they are ineffective on small quantities of seed (Brown et al. 1983, Mangelsdorfet al. 1957).

A rotary seed processor for improving seed quality of chaffy prairie grass seed was designed by K.P. Vogel and built according to his specifications by Precision Machine Company (Precision Machine Company, Inc. 2933 N 36 ${ }^{\text {th }}$ Street, Lincoln, Nebr. 68504) ${ }^{1}$. The processor (Figs 1 and 2) consists of a metal cylinder $(30 \mathrm{~cm}$. diameter $\times 46 \mathrm{~cm}$ long) that is lined with corrugated rubber. It has a rotating center shaft that has 4 equidistantly spaced, flexible, rubber paddles. A top-opening, full length door allows seed to be easily placed into the unit. The cylinder can be inverted to dump out the processed seed. 


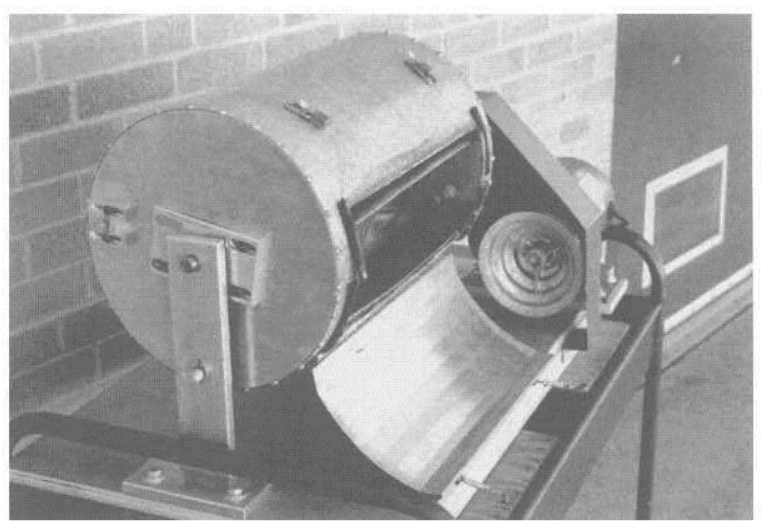

Fig. 1. The rotary chaffy seed processor with lid opened and processing cylinder rotated for dumping seed.

The unit can process very small seed lots, including seed harvested from a single plant but larger seed lots must be processed in 2 liter sublots. Extent of processing can be controlled by varying shaft rotation speed and processing time. A small seed cleaning study was conducted to provide information on processing effects on seed bulk density and germination.

\section{Materials and Methods}

Three seed lots each of big bluestem and indiangrass (Table 1) from the USDA-ARS grass breeding program and the University of Nebraska Foundation Seed Division were used in this study. Seed of the experimental strains (KawC1, Pawnee C1, and NE 54 C1) were obtained by threshing with a small plot thresher. The Foundation Seed lots (Pawnee, Oto, and Holt) were the product of combined seed cleaned on conventional grass seed cleaning equipment (Mangelsdorf et al. 1957). Each seed lot was subdivided into 3 sublots. Each sublot was processed separately to provide an estimate of variability in the cleaning process.

Prior to processing, each sublot was sampled for germination tests and bulk density ( $\mathrm{g}$ /liter) was determined using a standard bushel weight apparatus. Seed in the bushel weight catch bucket were weighed and the weight was divided by the liter volume to obtain bulk density. Bulk density of the processed seed was determined using the same procedure. About 2 liter of unprocessed seed were placed in the processor. The unit was operated for 90 $\mathrm{sec}$ for big bluestem and $180 \mathrm{sec}$ for indiangrass at 120 revolutions per minute. After processing, a small laboratory seed air blower (Air Blast Seed Cleaner, Almaco, Box 296, 99M Avenue, Nevada, Iowa, 50201) ${ }^{1}$ was used to separate the processed material into seed and chaff. The chaff consisted of awns, chaff, pubes-
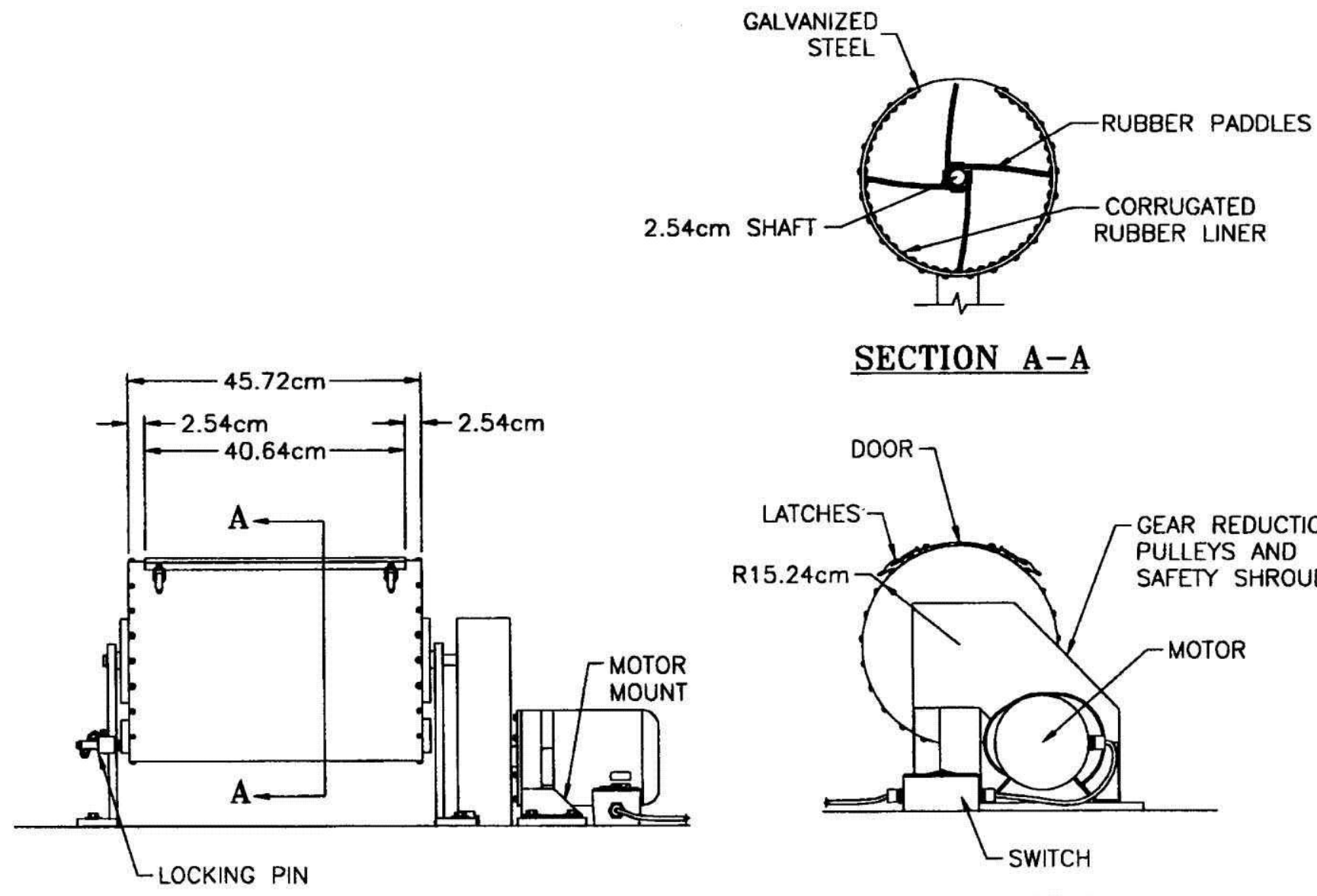

FRONT VIEW

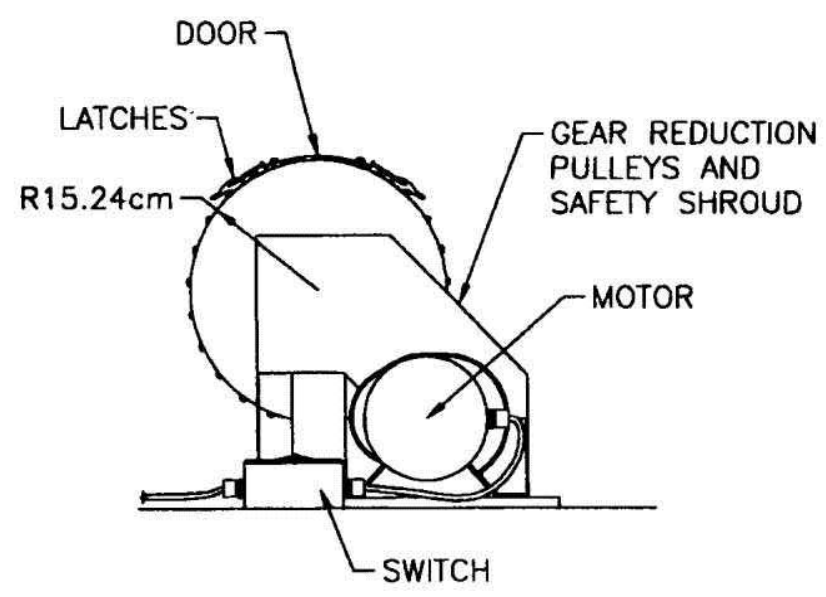

SIDE VIEW

Fig. 2. Rotary seed processor, front, side, and cross section (A-A) views. 


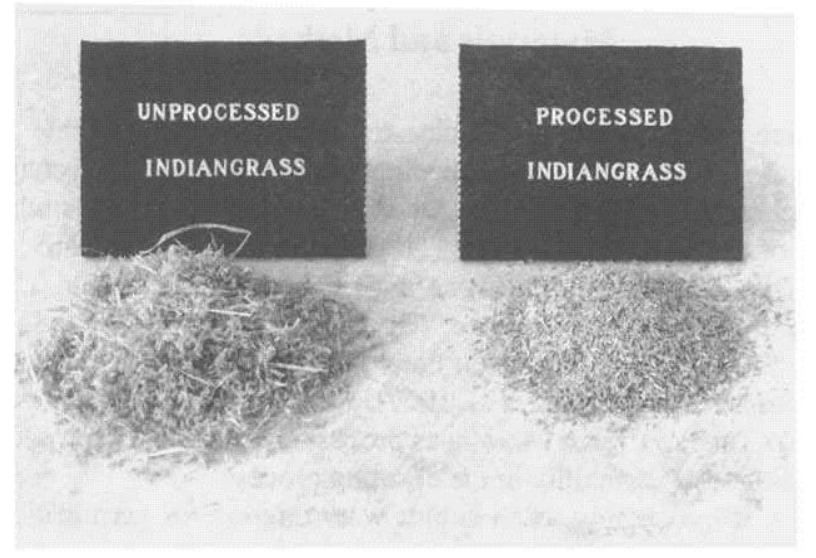

Fig. 3. Unprocessed (left) and processed (right) indiangrass seed.

cence, culm segments, and light florets. Hand screens were used to remove stems and other chaff from the processed seed that had not been removed by the seed blower. Screen sizes openings were $4 \mathrm{~mm} \times 19 \mathrm{~mm}(10 / 64 \mathrm{in} \times 3 / 4 \mathrm{in})$ and $2.5 \mathrm{~mm} \times 19 \mathrm{~mm}(6 / 64$ in and $3 / 4$ in). Both screens were used in consecutive order for big bluestem. Only the finer screen was used for indiangrass. Processed seed and chaff were weighed to determine percentage of processed seed recovery and material lost in the conditioning process.

One $\mathrm{g}$ of material was subsampled from the unprocessed seed, processed seed, and chaff for each sublot and placed in plastic germination boxes on germination blotter paper. The blotter paper and seeds were saturated with water and the boxes were covered with plastic lids and placed in a refrigerator for prechilliing. The material was prechilled at $5^{\circ} \mathrm{C}$ for 2 weeks following A.O.S.A. procedures (A.O.S.A.1970). The boxes were then placed in a germination cabinet set at $20^{\circ} \mathrm{C}$ (night) and $30^{\circ} \mathrm{C}$

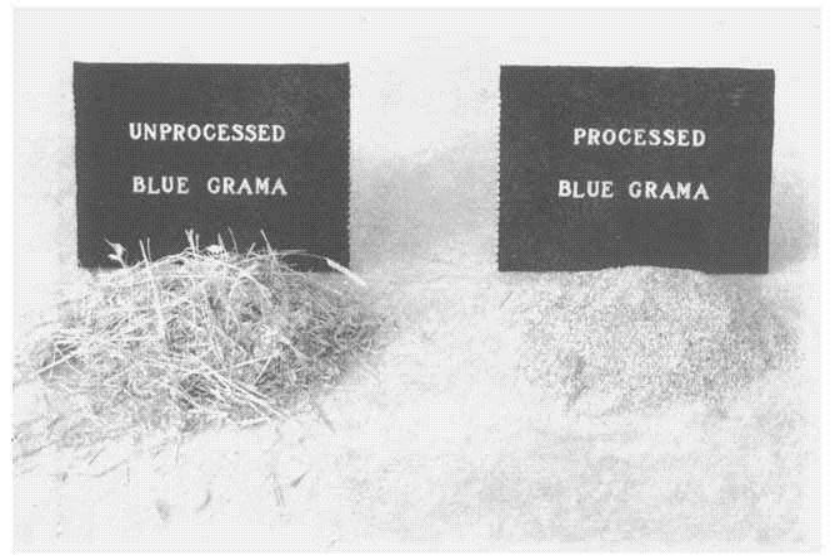

Fig. 4. Unprocessed (left) and processed (right) blue grama seed.

(day) with a day length of 8 hours (A.O.S.A, 1970). The germinated seed/g was determined by counting the number of seedlings following 2 weeks in the germination cabinet.

\section{Results and Discussion}

The processed seed consisted largely of intact florets containing caryopses but with awns, pubescence, and attached appendages removed (Figs. 3 and 4). The conditioning process improved the bulk density of all seed lots including those that had gone through the conventional seed cleaning procedures of a foundation seed program (Table 1). The germinated seedlings/g obtained from the processed seed were 2.5 to over 25 fold greater than the number of seedlings/g obtained from the unprocessed seed (Table 1). The chaff contained some seed that germinated but in comparison to the processed seed, the number of

Table 1. Effects of processing big bluestem and indiangrass seed with a rotary seed processor on seed recovery, seed bulk density, and germinated seeds/g.

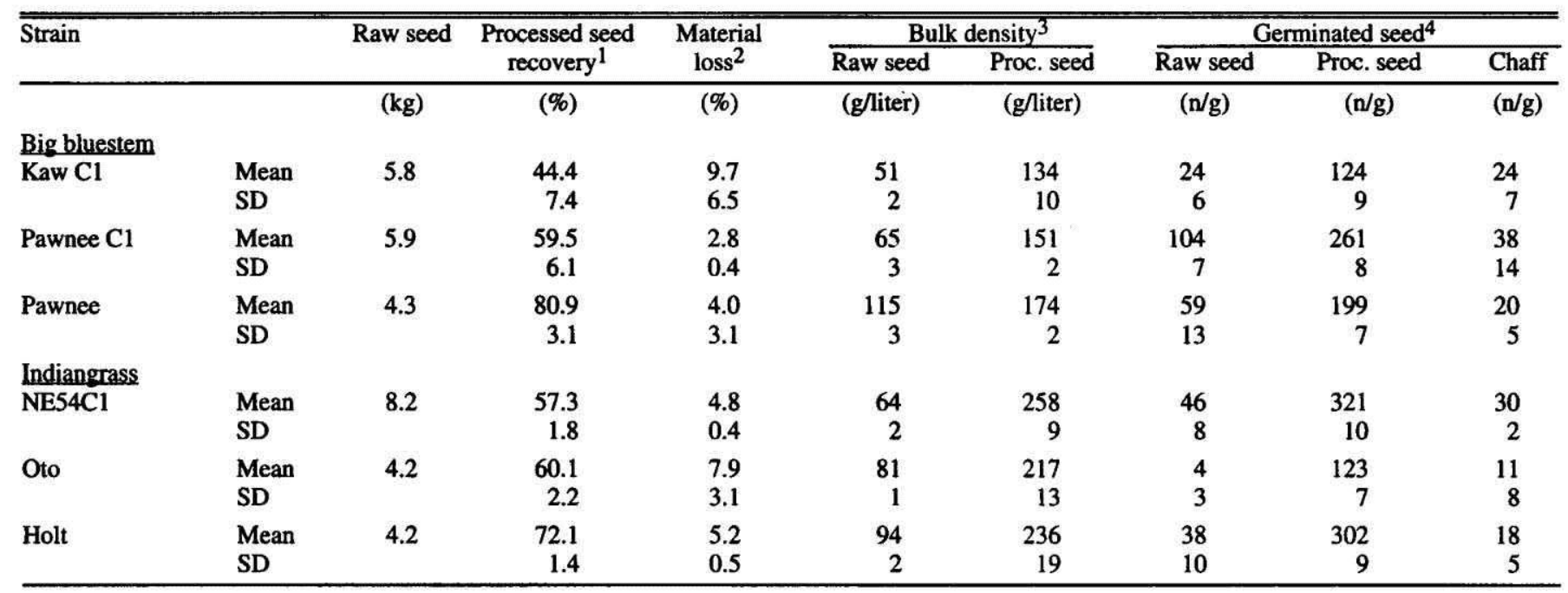

1Processed seed recovery $\%=$ Processed seed wt./unprocessed lot wt. $* 100$.

${ }^{2}$ Material loss through processing $=1-[$ (processed seet $w t .+$ chaff $\left.w t.) / u n p r o c e s s e d ~ l o t ~ w t . ~\right] * 100$.

${ }^{3}$ Bulk density $=$ g/liter of sample measured in a standard grain bushel weight test apparatus and converted to g/liter.

${ }^{4}$ Germinated seed $=$ number of seed $(\mathbf{n}) / g$. 
seedlings/g was small. Figures 3 and 4 illustrate the improvement in seed quality that can be obtained by using the seed conditioner.

Our results demonstrate that the rotary seed processor greatly improves the quality of chaffy grass seed for use in research trails. If the processing time and rotor-rotation speed are set properly, the grass seed units remain intact, i.e., the caryopses remains enclosed by lemmas, paleas, and glumes (varies with species). We have been using the original rotary seed processor and an updated version since 1977 to prepare or condition chaffy seed for use in plant breeding, revegetation, and herbicide trials. Our seed conditioning process has 3 steps. The first step is the use of the rotary seed processor for removing seed appendages and chaff from the seed. In the next step, the seed is passed through the Air Blast Cleaner ${ }^{1}$ to remove seed appendages and chaff disarticulted from the seed in the rotary seed processor. In the final step a bench top type Clipper Cleaner (Clipper Separation Technologies, P.O. Box 256, 805 South Decker Drive, Bluffton, Indiana 46714) ${ }^{1}$ with paired sieves is used to remove stem fragments and other material that we removed with hand screens in this study. This 3 step process has enabled us to reliably obtain uniform stands of prairie grasses when used in conjunction with well calibrated plot drills.

\section{Literature Cited}

Association of Official Seed Analysts. 1970. Rules for Testing Seeds. Proceeding of the Association of Official Seed Analysts. Vol 60. No 2.

Brown, R.R., J. Henry, and W. Crowder. 1983. Inproved processing for high quality seed for big bluestem (Andropogon gerardi) and yellow indiangrass (Sorghastrum nutans). p. 272-274. In: J.A. Smith and V.W. Hays (eds). Proc. 14th. Int. Grassl. Congr., Lexington, Ky. 15-24 June, 1981. Westview Press, Boulder, Colo.

Mangelsdorf, Albert H., James Henderson, and G. Burns Welch. 1957. Processing field seed. P. 182-209. In: W.A. Wheeler and D.D. Hill. Grassland Seeds. D. Van Nostrand, Inc. Princeton, N.J.

Vogel, Kenneth P. 1978. A simple method of converting rangeland drills to experimental plot seeders. J. Range Manage. 31:235-237.

${ }^{\mathrm{T}}$ Names of products are included for the benefit of the reader and do not imply the endorsement by USDA or the Univ. of Nebraska. 